\title{
The Capital Market Reaction to the Recognition of the City of Jerusalem as the Capital City of Israel
}

\author{
H. Gifani ${ }^{1}$, L. M. Nurafiati ${ }^{2}$, B. Wicaksono ${ }^{3}$ \\ 1st Faculty of Economics and Business, Diponegoro University, Indonesia ${ }^{1,2,3}$
}

\{hgifani@emailaddress.com\}

\begin{abstract}
Capital markets are inseparable from the environmental influence of one of the political events as a non-economic environmental influence. Capital markets efficiently react to information related to the share price because of an event. The focal point in the research centres on capital markets reacting to information and can be seen from two changes in stock prices and stock trading activities. The purpose of this research is to explain the difference of average abnormal return and average trading volume activity between before and after the recognition of the event of Jerusalem as the capital city of Israel. This research using event study with a purposive sampling method and obtained a sample of 68 stock indices. The data analyses were used statistic descriptive analyses, stationary test, cointegration test, Kolmogorov-Smirnov test for data normality test, and hypothesis testing used Paired Sample T-test for data which are normally distributed. The result of the Paired Sample T-test showed that there is an average abnormal return and there is no average trading volume activity between before and after the recognition of Jerusalem as the capital city of Israel. Information content in research affects investment because it fully reflects the information published. Affecting the share price and investors reacting to absorbing abnormal returns towards a new balance price.
\end{abstract}

Keywords: average abnormal return, average trading volume activity, event study.

\section{Introduction}

Capital markets are inseparable from the environmental influence of one of the political events as a non-economic environmental influence. Capital markets efficiently react to information related to the share price because of an event. The information signals for investors to make decisions that affect price fluctuations and capital market volumes [1]. The non-economic information that fuels the effects of world capital markets is the election of Donald Trump as President of the United States. The presidential election has led to a weakening of stock price indexes in some countries as investors worry about policies that will be implemented in the era of Donald Trump's leadership (detikfinance.com). One of the decisions issued after Donald Trump was elected was that he issued a policy regarding the unilateral recognition of the city of Jerusalem as the capital of Israel (tribunnews.com). This 
raises the pros and cons of draft resolution A/ES-10L22 on the status of the city of Jerusalem with 128 countries rejecting the decision.

The focal point in the research centres on capital markets reacting to information and can be seen from two changes in stock prices and stock trading activities [2]. Changes in share price can be measured using abnormal returns, while stock trading activity can be measured using trading volume activity [3]. The information question in the event of the recognition of the City of Jerusalem as the Capital of Israel which received condemnation from various parties, but the scope of the country to be examined is limited to stock indices located on the stock exchanges of countries in continental Europe, the Americas, and Asia-Pacific. This research period is limited to $t-5$ prior to the event, at the time of the event occurred on December 6, 2017, and at $\mathrm{t}+5$ events occurred to find out the average difference from abnormal return and trading volume activity in that time span.

\section{Literature Review}

\subsection{Signal Theory}

Signal theory originated from George Akerlof's research (1970) which introduced asymmetric information. The principle in signal theory is "actions convey information" i.e. each action complains of information. This is due to asymmetric information or conditions when a party has more information than the other party [4]. Information from market reactions gives positive and negative signals when the information gives a positive signal then the market reaction indicates a rise in the share price. Meanwhile, when the information gives a negative signal, the share price will not change or may decrease Brigham and Houston.

\subsection{Hypothesis}

\section{a) The Effect of Political Events on Average Abnormal Return}

Return is the result of an investment in the form of profit and alongside the risk to the investment that the investor has made. The study used an average abnormal return which is the average of the abnormal return of all stocks analysed and the results will show an average return that does not match the expected return within a given period. Previous research conducted by Nurhaeni, Ardiansari and Saputra, regarding political events against abnormal average returns showed results that there were significant differences between before and after political events. In contrast, research conducted by Pratama et al, Sari et al, and showed no significant difference between before and after political events against abnormal average returns.

The relationship between political events and average abnormal returns based on previous theories and research in this study relates to the event of recognition of the city of Jerusalem as information that is expected to provide market reaction and is indicated by changes in abnormal average return. The signals contained in the information will affect the rise and fall of the share price. $\mathrm{Ha}_{1}$ : There is a positive relationship between the average abnormal return and the stock indices of countries in Europe, the Americas, and the Asia-Pacific between before and after the event.

\section{b) The Effect of Political Events on Average Trading Volume Activity}


Trading volume activity is a gauge indicator of stock activity to see the assessment of financial report information by investors based on trading decisions Husnan et al,. Liquid securities signify securities that sell quickly. This liquidity can be seen in trading volume activity [4] Trading volume becomes an important piece of information that signals the next price movement. Previous research on political events on average trading volume activity conducted by Nurhaeni, Sari et al, and Nambela showed there was a significant difference between before and after the event. In contrast, research conducted by Ardiansari and Saputra and Rohmiyati (showed no significant difference in average trading volume activity between before and after political events. $\mathrm{Ha}_{2}$ : There is a positive relationship between the average trading volume activity and the stock indices of countries in Europe, the Americas, and the Asia-Pacific between before and after the event.

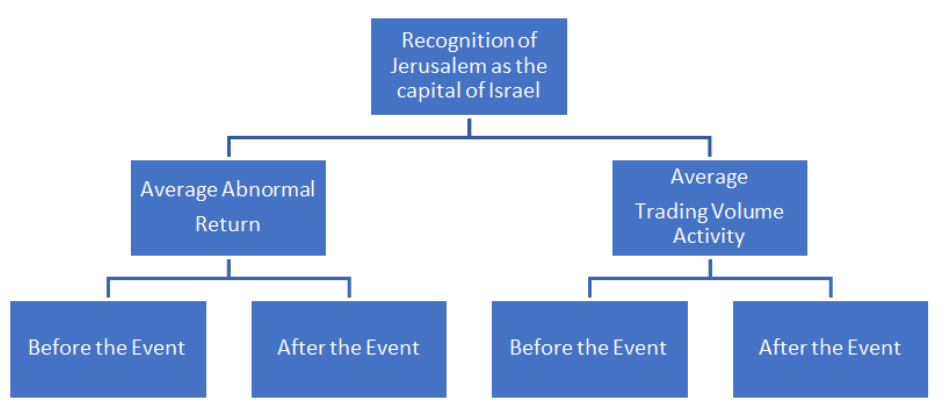

Fig. 1. Conceptual Framework

\section{Research Methodology}

The type of research used is research based on event study. According to Nurhaeni, the event study is a statistical design that describes a research technique to assess the impact of an event on the share price and trading volume. The event study studied the reactions of the capital market against the information content of an event as a specific announcement [5]. The period of the event is used as in Figure 2. is 5 days before December 6, 2017 and 5 days after the event with an estimated period of 30 days. A relatively short period of events aims to reduce the confounding effect [6].

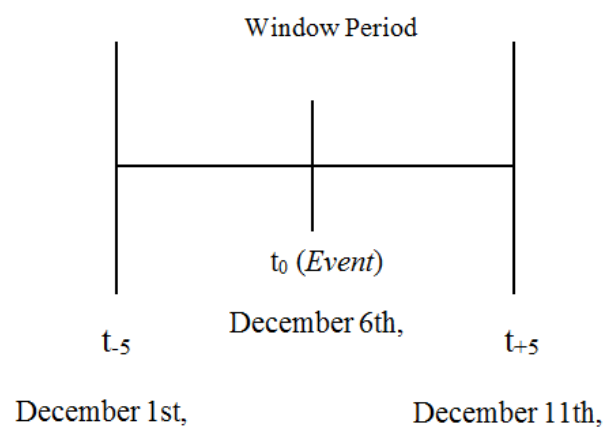

Fig. 2. Estimation Period and Research Window Period. 
The population in this study is an index on countries in Europe, America, and Asiapacific. The research focused on the three continents due to the considerable pros and cons of countries involved as members of the United Nations in giving an opinion on the event of the recognition of Jerusalem as the Capital of Israel. Based on this, 78 countries with 303 stock indices were found as research populations. Using a purposive sampling method, which is sampling based on a particular consideration, 68 countries with 68 indexes were found as research samples. The histories criteria used to select the sample include: countries located in the European, American, and Asia-Pacific regions; countries have at least one stock index with historical data closing price according to the period of the event; and the stock index of the country as a sample is the main stock index according to the data required in the event period.

The closing price data of each country's indexes in the study were processed using the help of Microsoft Excel 2010 software. The software is used to calculate the closing price and trading volume of the stock into an abnormal average return and average trading volume activity. Tests conducted to compare both alternative hypotheses consist of descriptive statistics, Dickey-Fuller Augmented Stationary Test (ADF), co-integration test, and normality test, and t-test using the help of SPSS 21 and E-Views 9 software. The variables used in the study consisted of (1) Average Abnormal Return (AAR) as the average of abnormal returns. Abnormal return is obtained from the difference in return realization and expected return according to the following formula (Hartono, 2016):

$\operatorname{RTN}_{i, t}=R_{i t}-E\left(R_{i, t}\right)$

Return realization is obtained from the current price difference with the price in the previous period as in the following formula. [3]:

$R_{i, t}=\frac{P_{i, t}-P_{i, t-1}}{P_{i, t-1}}$

While expected return based on the mean-adjusted model is obtained from the day of dividing the realization return by the estimated period (30 days) as in the following formula (Hartono, 2016):

$E\left(R_{i, t}\right)=\frac{\sum_{j=t 1}^{t 2} R_{i, j}}{T}$

Average Abnormal Return (AAR) is obtained from dividing the amount of abnormal return divided by the number of securities affected by the announcement of events as in the formula (Hartono, 2016):

$\operatorname{RRTN}_{t}=\frac{\sum_{i=1}^{k} R R T N_{i t}}{k}$

Average Trading Volume Activity (ATVA) as the average of trading volume activity, in this case, trading volume activity, is the amount of stock trading volume at a time according to the formula: 
$T V A=\frac{\sum \text { the numbers of stocks traded at a times }}{\sum \text { the number of stocks of a company outstanding at a times }}$

While Average Trading Volume Activity (ATVA) is the result of the number of TVA divided by the number of securities as in the following formula:

$A T V A_{t}=\frac{\sum_{i=1}^{k} A T V A_{i t}}{k}$

The source of the data in the form of historical closing price data is obtained from the official website of Yahoo Finance and Investing.com which provides historical data on stock price indexes and trading volumes across continental Europe, America, and Asia-Pacific countries. Stationary testing of a time series data can predict the statistical properties in the future based on historical data that has occurred. This test uses the Dickey-Fuller Augmented root unit (ADF) test provided that if the absolute value of the ADF statistic is greater than the critical value of McKinnon's statistical distribution then the data is observed stationery. However, if the absolute value of the ADF statistics is smaller than the critical value of McKinnon's statistical distribution then the observed data is not stationary [7].

The co-integration test was developed by Engle \& Granger. To test the co-integration can be done with the Engle \& Granger test method and the Johansen test Rosadi. In this research used co-integration tests by Johansen were used to determine the co-integration of several variables [7]. The concept in this test is that two stationary variables will be co-integrated if the combination is also linear. If the time series variable is co-integrated then there is a longterm relationship between variables [1]. The normality test used is the Kolmogorov-Smirnov normality test. Then what will be observed is a significant 2-tailed value. If the result is more than a significant number of 0.05 then the residual data is distributed normally, otherwise if the result is less than the significant number 0.05 then the residual data is not distributed normally.

The results of the normality test will determine the different tests to be used. If the data is distributed normally then used Paired Sample T-test whereas if the data is not distributed normally then the Mann-Whitney test is used. Using the significance level $\alpha=5 \%(0.05)$ hypothesis testing criteria is accepted if the significance value is less than 0.05 meaning there is a difference in average abnormal return and average trading volume activity on the stock indices of countries in Europe, America, and Asia-Pacific between before and after the event of the recognition of Jerusalem as the Capital of Israel. The hypothesis will be rejected if the significance value is more than 0.05 . That is, there is no difference in average abnormal return and average trading volume activity on country stock indices in average trading volume activity in Europe, America, and Asia-Pacific between before and after the event of the recognition of Jerusalem as the Capital of Israel.

\section{Results and Discussion}

Stock index closing price data is used to look for abnormal average return while stock trading volume data is used to search for average trading volume activity. This process is assisted by Microsoft Excel 2010 software. The results of these calculations are then analyzed using the SPSS 21 and E-Views 9 applications according to the tests that have been prepared. The results of the descriptive statistical analysis of abnormal return and average trading volume activity can be summed up the kurtosis value used to determine the histogram tape in 
the average abnormal return table of $98,340(98,340>0)$ and in the average trading table the volume activity result is $59,890(59,890>0)$. Both results show that the kurtosis average value is abnormal return, and the average trading volume activity is more than 0 . This indicates the value of kurtosis "tapered" or has one dominating value.

At the skewness or histogram grip on the table the average abnormal return shows a yield of $-0.004(-0.004<0)$. The results showed the distribution of skewness data was negative because the value was less than 0 . While in the table the average trading volume activity results show a skewness value of $7,448(7,448>0)$. The results show the distribution of skewness value is positive because it is more than 0 .

\subsection{Stationary Test}

Stationary test results using Augmented Dickey-Fuller Test with level $1^{\text {st }}$ difference on average abnormal return (AAR) and average trading volume activity (ATVA) between before and after event can be seen in Table 1 .

Table 1. Stationary Test Results

\begin{tabular}{lccc}
\hline \multicolumn{1}{c}{ Variable } & ADF Test Statistic & Critical Value 5\% & Exp. \\
\hline AAR Before Events & $-18,3104$ & $-2,86998$ & Stationary \\
AAR After Events & $-18,3839$ & $-2,86998$ & Stationary \\
ATVA Before Events & $-21,0306$ & $-2,86993$ & Stationary \\
ATVA After Events & $-21,2337$ & $-2,86993$ & Stationary \\
\hline
\end{tabular}

Source: E-Views 9 Output, 2018

Based on the results of the table can be seen variable data abnormal average return and average trading volume activity has been stationary at the first integration level.

\subsection{Co-integration Test}

Table 2. Co-integration Test Results

\begin{tabular}{lccccc}
\hline \multicolumn{1}{c}{ Variable } & $\begin{array}{c}\text { Trace } \\
\text { Statistics }\end{array}$ & $\begin{array}{c}\text { Critical } \\
\text { Value 0.05 }\end{array}$ & $\begin{array}{c}\text { Max-Ergen } \\
\text { Statistic }\end{array}$ & $\begin{array}{c}\text { Critical } \\
\text { Value 0.05 }\end{array}$ & Exp. \\
\hline AAR Before Events & 198,8657 & 69,8189 & 105,2182 & 33,8769 & Co-integration \\
ATVA Before Events & 173,3054 & 47,8561 & 119,0591 & 27,5843 & Co-integration \\
AAR After Events & 226,7490 & 69,8189 & 117,2134 & 33,8769 & Co-integration \\
ATVA After Events & 76,1357 & 47,8561 & 25,4555 & 27,5843 & Co-integration \\
\hline \multicolumn{7}{c}{ Source: E-Views 9 Output, 2018 }
\end{tabular}

The results of the co-integration test on the average abnormal return (AAR) and average trading volume activity (ATVA) between before and after the event can be seen in Table 2 . Based on the results of Table 2 it can be noted that there is a co-integration of variables with a significance rate of 0.05 or $5 \%$. So, it can be inferred on the variables tested to have a relationship of balance and similarity of movement over a long period of time and each variable with a short period of time will adjust each other.

\subsection{Normality Test}

Normality test results on average abnormal return and average trading volume activity using Kolmogorov-Smirnov test can be seen in Table 3 and Table 4. 
Table 3. Average Abnormal Return Normality Test Results

\begin{tabular}{|c|c|c|c|c|c|c|}
\hline & Kolmogor & $\mathrm{v}-\mathrm{Sn}$ & irnov ${ }^{a}$ & Shapiro-I & Vilk & \\
\hline & Statistics & Df & Sig. & Statistics & Df & Sig. \\
\hline Before & .397 & 340 & .000 & .208 & 340 & .000 \\
\hline After & .393 & 340 & .000 & .205 & 340 & .000 \\
\hline
\end{tabular}

Based on the results of the Kolmogorov-Smirnov normality test and the Shapiro Wilk test showed a significance value on the average abnormal return prior to the recognition event of the City of Jerusalem of $0.397>0.050$. Meanwhile, the value of significance after the recognition of the City of Jerusalem amounted to $0.393>0.050$.

Table 4. Average Trading Volume Activity Normality Test Results Between Before and After Events

\begin{tabular}{|c|c|c|c|c|c|c|}
\hline & \multicolumn{3}{|c|}{ Kolmogorov-Smirnova } & \multicolumn{3}{|c|}{ Shapiro-Wilk } \\
\hline & Statistics & Df & Sig. & Statistics & df & Sig. \\
\hline Before & .430 & 340 & .000 & .181 & 340 & .000 \\
\hline After & .423 & 340 & .000 & .198 & 340 & .000 \\
\hline
\end{tabular}

Based on the results of the Kolmogorov-Smirnov normality test and the Shapiro Wilk test shows the value of the average trading volume activity prior to the recognition of the City of Jerusalem of $0.430>0.050$. Meanwhile, the value of significance after the recognition of the City of Jerusalem amounted to $0.423>0,050$.

\subsection{Hypothesis Test}

The results of the hypothesis test in this study can be seen in Table 5 and Table 6 .

\section{a) Different Test Paired Sample T-test no Average Abnormal Return Between Before and After Events for $\mathrm{Ha}_{1}$}

The first alternative hypothesis $\left(\mathrm{Ha}_{1}\right)$ in this study is thought to have been an abnormal average return on the stock indices of countries in Europe, the Americas, and Asia-pacific between before and after the event of the recognition of Jerusalem as the Capital of Israel. This hypothesis test was then conducted with a different Paired Sample T-test at a significance level of 0.05 .

Table 5. Paired Sample T-test Average Abnormal Return Test Results

\begin{tabular}{ccc}
\hline & Df & Sig (2-tailed) \\
\hline AAR Before and After & 339 & .000 \\
\hline Source: SPSS 21 Output, 2018
\end{tabular}

Based on table 5 variables the average abnormal return between before and after the event of recognition of the City of Jerusalem has sig. (2-tailed) count by $0,000<0.05$ which is smaller than sig. table, so $\mathbf{H a}_{1}$ is accepted. This means there is a significant difference in the average abnormal return between before and after the recognition of the City. At the time of 5 days before the event the stock price index in 68 countries tends to increase and decrease in the 2 days before the event. The market response began to increase on the first day after the 
recognition of the City of Jerusalem by 0.104 and continued to rise on the second day after a significant recognition event of 12,103 . This proves that the market response is very high to the recognition of the City of Jerusalem.

\section{b) Test different Paired Sample T-test there is Average Trading Volume Activity Between Before and After Events for $\mathrm{Ha}_{2}$}

The second alternative hypothesis $\left(\mathrm{Ha}_{2}\right)$ in the study is thought to have been a difference in average trading volume activity on the stock indices of countries in Europe, the Americas, and Asia-pacific between before and after the event of the recognition of Jerusalem as the Capital of Israel. This hypothesis test was then conducted with a different Paired Sample Ttest at a significance level of 0.05 .

Table 6. Different Paired Sample T-test Average Trading Volume Activity Test Results

\begin{tabular}{ccc}
\hline & Df & Sig (2-tailed) \\
\hline ATVA Before and After 339 & .950 \\
\hline Source: SPSS 21 Output, 2018
\end{tabular}

Based on table 6 variable average trading volume activity between before and after the event of recognition of the City of Jerusalem has sig. (2-tailed) count is $0.950>0.05$ which is greater than sig. table, so $\mathbf{H a}_{2}$ is rejected. This means there is no significant difference in average trading volume activity between before and after the recognition of the City of Jerusalem. At the time of 3 days before the event the volume of stock trading in 68 countries tends to increase and decrease on the day before the event. The market response began to increase on the first day after the recognition of the City of Jerusalem amounted to 568.13 of the $\mathrm{T}-1$ events and continued to rise at $\mathrm{t}+2$ after the event of 620.99 . This proves that trade volume activity responds to the recognition of the City of Jerusalem conducted by the President of the United States.

Table 7. Summary of Hypothesis Test Results

\begin{tabular}{ccc}
\hline Hypothesis & Variable & Results \\
\hline $\mathrm{Ha}_{1}$ & Average Abnormal Return & Accepted \\
$\mathrm{Ha}_{2}$ & Average Trading Volume & Rejected \\
& Activity & \\
\hline \multicolumn{3}{c}{ Source: SPSS 21 Output, 2018 }
\end{tabular}

The results showed that the content of information in the event of recognition of the City of Jerusalem influenced investors significantly in investing in the capital market and obtained a significant abnormal average return around the event. From these results the capital markets on the European, American, and Asia-Pacific stock exchanges support the efficiency of the half-strong form market. The market efficiency of the half-strong form occurs if the price of the security fully reflects the published information. Such information affects the securities prices of all companies listed on the stock market. Investors react quickly to absorb abnormal returns towards a new balance (Hartono, 2017).

Nurhaeni (2009) means if there is an increase in demand (demand) shares then the event is "good news". Meanwhile, if in the volume of stock trading that increases is the sale (supply) then the event is " bad news" which results in investors selling the shares owned due to the uncertain capital market situation. The results of the study prove there is no difference in average trading volume activity between before and after the event of recognition of the City 
of Jerusalem so that demand (demand) of stocks is less and the sale (supply) tends to increase so that it can be concluded that the event is "bad news" for investors. The volume of stock trading after an event tends to decrease from the trading volume before the event.

\section{Limitation and Recommendation}

The conclusion in the study is that there is a positive relationship on the average abnormal return between before and after the event of the recognition of the city of Jerusalem by the President of the United States. Furthermore, there is a negative relationship to the average trading volume activity between before and after the recognition of the city. For issuers, the results of this research are suggested to be used as one of the considerations in determining company policy in the event of an international political event to provide accurate and fast information about the condition of a country index in the general public. The index information is a sign that indicates economic development and serves as a deflator of a country's inflation rate.

For investors, it is advisable to minimize the risk at the time of the event. Investors should be able to analyse the information precisely related to the share price and the content of information whether it is bad news or good news. Investors are also advised not to trust news that does not have a reliable source. The act of analysing quickly and appropriately is intended so that investors can make the right decisions in determining portfolio diversification for investors. Investor decisions will affect fluctuations in stock prices and trading volume. This is indicated by a rise in demand and followed by a rise in the share price.

\section{References}

[1] S. A. Ardiansari A, 'Capital Market's Reaction Towards 2014 Working Cabinet.', J. Din. Terpadu., vol. 6(1):, pp. 62-72, 2015.

[2] N. N, 'Dampak pemilihan umum legislatif Indonesia tahun 2009 terhadap abnormal return dan aktivitas volume perdagangan saham di BEI (Uji Kasus Pada Saham yang Terdaftar dalam Kelompok Perusahaan LQ 45)', 2009.

[3] H. J, Teori Portofolio Dan Analisis Investasi, Edisi Kese. 2017.

[4] H. MA, 'Pengaruh Stock Split Announcement Terhadap Volume Perdagangan dan Return.', Manag. Anal. Journal., doi: doi:10.15294/maj.v2i1.

[5] W. R. Barokah S, 'Pengujian Abnormal Return Peluncuran Indeks Mnc36', Manag. Anal. Journal., vol. 5(2):136-1, 2016.

[6] A. R. Purbawati TD, Arifati R, 'Pengaruh Pemecahan Saham (Stock Split) Terhadap Trading Volume Activity dan Average Abnormal Return Pada Perusahaan Yang Terdaftar Di Bursa Efek Indonesia', J. Accounting., vol. 2(2):1-12, 2016.

[7] W. A, . Ekonometrika: Pengantar Dan Aplikasinya. 2017. 